Tjalling C. Koopmans Research Institute

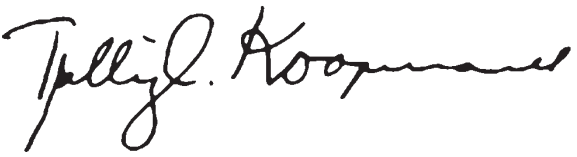

Discussion Paper Series nr: 09-25

\title{
Pension funds' asset allocation and participant age: \\ a test of the life-cycle model
}

Jacob A. Bikker

Dirk W.G.A. Broeders

David A. Hollanders

Eduard H.M. Ponds 


\section{Tjalling C. Koopmans Research Institute Utrecht School of Economics Utrecht University}

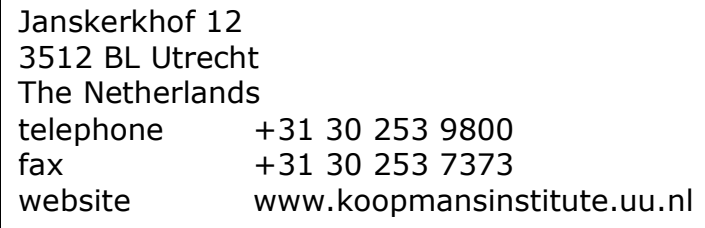

The Tjalling C. Koopmans Institute is the research institute and research school of Utrecht School of Economics.

It was founded in 2003, and named after Professor Tjalling C.

Koopmans, Dutch-born Nobel Prize laureate in economics of 1975.

In the discussion papers series the Koopmans Institute publishes results of ongoing research for early dissemination of research results, and to enhance discussion with colleagues.

Please send any comments and suggestions on the Koopmans institute, or this series to J.M.vanDort@uu.nl

ontwerp voorblad: WRIK Utrecht

\section{How to reach the authors}

Please direct all correspondence to the first author.

\section{Jacob A. Bikker ${ }^{* \#}$}

Dirk W.G.A. Broeders*

*De Nederlandsche Bank (DNB)

Supervisory Policy Division, Strategy Department

P.O. Box 98

1000 AB Amsterdam

The Netherlands

E-mail: J.A.Bikker@DNB.nl Dirk.broeders@DNB.nl

\#Utrecht University

Utrecht School of Economics

Janskerkhof 12

3512 BL Utrecht

The Netherlands.

Eduard Ponds

David Hollanders

Tilburg University

Postbus 90153

5000 LE Tilburg

The Netherlands

E-mail: e.h.m.ponds@uvt.nl

d.a.hollanders@uvt.nl 
Utrecht School of Economics

Tjalling C. Koopmans Research Institute

Discussion Paper Series 09-25

\title{
Pension funds' asset allocation and participant age: a test of the life-cycle model
}

\author{
Jacob A. Bikkerab \\ Dirk W.G.A. Broeders ${ }^{a}$ \\ David A. Hollanders ${ }^{c}$ \\ Eduard H.M. Pondsc

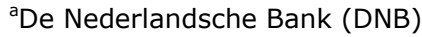 \\ the Netherlands \\ bUtrecht School of Economics \\ Utrecht University \\ ${ }^{\circ}$ Tilburg University \\ the Netherlands
}

September 2009

\begin{abstract}
This paper examines the impact of participants' age distribution on the asset allocation of Dutch pension funds, using a unique data set of pension fund investment plans for 2007. Theory predicts a negative effect of age on (strategic) equity exposures. We observe that pension funds do indeed take the average age of their participants into account. However, the average age of active participants has been incorporated much more strongly in investment behaviour than the average ages of retired or dormant participants. This suggests that both employers and employees, who dominate pension fund boards, tend to show more interest in active participants. A one-year higher average age in active participants leads to a significant and robust reduction in the strategic equity exposure by around 0.5 percentage point. Larger pension funds show a stronger age-equity exposure effect than smaller pension funds. This age-dependent asset allocation of pension funds aligns with the original life-cycle model by which young workers should invest more in equity than older workers because of their larger human capital. Other factors, viz. fund size, funding ratio, and average pension wealth of participants, influence equity exposure positively and significantly, in line with theory. Pension plan type and pension fund type have no significant impact.
\end{abstract}

Keywords: Pension funds, strategic equity allocation, lifecycle saving and investing.

JEL classification: D91, G11, G23, H55, J14;

\section{Acknowledgements}

The authors thank Jack Bekooij for excellent research assistance, and Paul Cavelaars, Willem Heeringa, Bert Stroop, and participants of lunch seminars of Netspar (University of Tilburg, 16 April), DNB (21 April), 'Amsterdams Instituut voor Arbeidsstudies' (AIAS, 23 April) and SEO (University of Amsterdam, 6 July) for helpfulcomments. The views expressed in this paper are personal and do not necessarily reflect those of DNB or APG. 


\section{Introduction}

The main aim of this paper is to assess whether Dutch pension funds' strategic investment policies depend on the age of their participants. The strategic investment policy reflects the objectives of the pension funds, while the actual asset allocation may depart from the objective as a result of asset price shocks, since pension funds do not continuously rebalance their portfolios (Bikker, Broeders and De Dreu, 2009). In this paper, we focus particularly on the strategic allocation of equities and bonds as representing, respectively, risky and safe assets. The argument for age-dependent equity allocation stems from optimal life-cycle saving and investing models (e.g. Bodie et al., 1992; Campbell and Viceira, 2002; Cocco et al., 2005; Ibbotson et al., 2007). An important outcome of these models is that the proportion of financial assets invested in equity should decrease over the life-cycle, thereby increasing the proportion of the relatively safer bonds. The key argument is that young workers have more human capital than older workers. As long as the correlation between labour income and stock market returns is assumed to be low, a young worker may better diversify away equity risk with their large holding of human capital.

Dutch pension funds effectively are collective savings arrangements, covering almost the entire population of employees. Pension funds often take the characteristics of their participants on board in their decision-making on strategic investment allocation. We investigate whether - in line with the life-cycle saving and investing model - more mature pension funds pursue a more conservative investment policy, that is, whether they hold less equity in favour of bonds. An important feature of most Dutch pension funds is that they explicitly base their funding and benefit allocation decisions on intergenerational risk sharing, that is, nominal benefits are guaranteed, indexation is likely and pension premiums are adjusted, the latter two depending on the funding ratio. Effectively, intergenerational risk sharing extends the size of human capital in the risk bearing basis, as human capital is pooled, not only among contemporaries within a cohort, but also with other generations and even with future participants.

For pension funds' strategic asset allocation in 2007, we find that a rise in participants' average age reduces equity holdings significantly, as the theory predicts. A cross-sectional increase of active participants' average age by one year appears to lead to a significant and robust drop in strategic equity exposure by around 0.5 percentage point. Note that the participants' average age varies only across sectional as, for each pension funds, this variable is nearly constant over time. Considering this, the awareness of the optimal age-equity relationship for pension funds, and its incorporation in the strategic equity allocation, is remarkable. This negative equity-age relationship has been found in other studies as well. For pension funds in Finland, Alestalo and Puttonen (2006) report that a one-year average age increase reduced equity exposure in 2000 by as much as 1.7 percentage points. Likewise, 
for Switzerland in 2000 and 2002, Gerber and Weber (2007) report a negative relation between equity exposure and both short-term liabilities and age. The effect they find is smaller yet significant, as equity decreases by 0.18 percentage point if the average active participant's age increases by one year. For the US, Lucas and Zeldes (2009) did not observe a significant relationship between the equity share in pension assets and the relative share of active participants.

We find also that this equity-age relationship is not linear: active participants' average age has been incorporated much more strongly in investment behaviour than that of retired and dormant participants. This is in line with the observation that in principle, employers and employees, who dominate pension fund boards, tend to show more interest in active participants.

The set-up of this paper is as follows. Section 2 highlights the theoretical relationship between the average age of pension fund participants and the share of equity investments, stemming from the lifecycle saving and investing model. Next, we proceed with a description of important characteristics of pension funds in the Netherlands. Section 4 investigates the age-dependency of asset allocation empirically using a unique dataset of 472 Dutch pension funds at end-2007. The next section presents a number of variants of our model, which act as robustness tests. Section VI concludes.

\section{The role and determinants of equity in pension fund investments}

We start with discussing theoretical views on the suitability of equity in pension fund investment and thereafter consider the role of age as one of the determinants of the equity exposure. Two opposing views on optimal asset allocation by pension funds may be distinguished: the long-term strategy and the all-bonds strategy. Starting with the first one, we consider that a pension fund has to meet benefit promises to both current and future retirees. For a typical pension plan in the Netherlands, the duration of accrued benefits is between 15 and 20 years. Campbell and Viceira (2002) argue that the risks of the various asset categories are different for varying time horizons. So, portfolio choices by long-term investors will differ from those of short-term investors. Both short-term and long-term investors benefit from risk diversification across asset classes. As risk is horizon-dependent, long-term investors also benefit from any time diversification within asset classes. Some empirical research finds that stocks are less risky in the long run due to their mean reversion: the annualized standard deviation halves over a 25 year horizon (Campbell and Viceira, 2002; Hoevenaars, 2008). Besides, long-term investors may invest in less liquid assets such as real estate. Money market instruments are relatively safe for short-term investors, but not for long-term investors because of reinvestment risk, that is, uncertain future short-term interest rates. Apart from the favourable return-risk trade off in the long run, equities may partly hedge increasing wage- or inflation-indexed liabilities, due to the positive long-run correlation between stock returns, on the one hand, and wages and inflation on the other 
(Lucas and Zeldes, 2006). Bodie (1995) disputes that investment risk diminishes over time. He points out that prices of put options, insuring against a return below the risk-free rate of return, increase both theoretically and empirically with the lengthening of the horizon.

The all-bonds strategy argues that pension liabilities are by nature bond-like (Bodie, 1990; Bader and Gold, 2003). The value of these liabilities is equal to the value of the replicating portfolio consisting of a - usually indexed - bonds portfolio that matches timing, amount and creditworthiness of the promised benefits. Note that, of course, the funding decision does not change the liabilities, that is, the value of the promised benefits. A risky asset mix may have a high expected return, yet this comes with a mismatch risk, which has to be absorbed by one or more of the pension fund's stakeholders. In a perfect market setting, the cost of buying protection against that mismatch risk from the expected equity proceeds will leave the same return as an all-bonds strategy. A pension fund cannot add value by changing the asset mix. Assets held in an all bonds strategy are equal in value to those in an allequity strategy. Moreover a pension fund invests on behalf of the risk bearing stakeholders. In a perfect market, a pension fund can do nothing that individual stakeholders cannot do directly themselves. The best strategy would then be an all-bonds strategy with no mismatch risk at all. But the market is not perfect.

If a pension fund's only purpose were to secure pension promises (at any cost), it would always be fully funded and fully immunized, that is, matched. This is clearly not the case. Cui et al. (2009) argue that although a pension fund is a zero sum game in valuation terms, a mismatch strategy might enhance welfare on account of the intergenerational risk sharing argument. The data reveal that, at end-2007, most pension funds in the Netherlands did not hold an all-bonds mix. Pension funds attempt to earn a risk premium on the fund's assets. Therefore, pension funds' balance sheets are exposed to considerable mismatch risk in the hope of earning a risk premium on pension assets so as to avoid having to pay the full economic cost of the pension promise.

The strategic allocation to equities differ between pension funds that can be explained by differences in risk appetite, determined by factors as size, type of industry, funding ratio, maturity, and the like. The degree of maturity can be measured by the average age of the plan participants. This paper is oriented at the question what the impact is of participant age on the asset allocation. We put forward that the relationship between equity allocation and average age is negative in line with the lifecycle model.

In the late 1960s economists developed models which implied that individuals should optimally maintain constant portfolio weights throughout their lives (Samuelson, 1969; Merton, 1969). A restrictive assumption of these models was that investors are assumed to have no labour income (or 
human capital). As most investors do in fact have labour income, this assumption is unrealistic. If labour income is included in the portfolio choice model, individuals will optimally change their allocation of financial wealth over their life cycle. The optimal allocation will therefore also depend on the risk-return characteristics of their labour income and the flexibility in their labour supply. Bodie et al. (1992) studied the impact of labour flexibility on investment strategy. They found that investors with safe labour income should invest in riskier assets. The preferred allocation to risky assets should be based on total wealth, being the sum of financial wealth and human capital. As the size of human capital declines with age, the proportion of financial assets invested in equities should also decrease over the lifecycle, in favour of low-risk investments or safe bonds. Habit formation is a factor concerning preferences that is typically not taken into account in life-cycle models. It could further reinforce the negative age-dependence of stock-holdings, as older participants are more risk-averse.

Pension funds have participants in a wide range of ages, from just over 20 to over 100. In models of optimal life-cycle saving and investing, the age of the investor plays a key role. Therefore, the question is whether the average age of participants acts as a determinant of the asset allocation in the greater entity of pension funds, and to what extent (for an overview, see Bovenberg et al., 2007). The rationale is that young workers possess more human capital than older workers, where younger workers can diversify investment risk, assuming that human capital is a relatively safe, so bond-like, asset. The age-dependency of human capital results in a negative age-dependency of equity exposure. The basic version of the life-cycle model with risk-free human capital can be summarized by the following equation for the optimal fraction of stock investment, denoted $w$ :

$w=\frac{H+F}{F} \frac{\mu-R^{f}}{\gamma \sigma^{2}}$

Here $H$ is the human capital (the total of current and discounted future wages) of an individual, and $F$ is the person's current financial capital. The risk-premium of the stock market is given by $\mu-R^{f}$, while $\gamma$ and $\sigma^{2}$ denote, respectively, the individual's constant relative risk aversion and the variance of stock market returns. As can be seen, more human capital leads to higher optimal investment in stocks.

Not only do young workers have more human capital, they also have more flexibility to vary their labour supply - that is, to adjust the number of working hours or their retirement date - in the face of adverse financial shocks. Flexible labour supply acts as a form of self-insurance for low investment returns. Bodie et al. (1992) show that this reinforces the optimality result, i.e. that young workers should have more equity exposure. Teulings and De Vries (2006) calculate that young workers should 
even go short in bonds equal to no less than 5.5 times their annual salary in order to invest in stock. ${ }^{2}$ The negative age-dependency of asset holdings corresponds to the rule of thumb that an individual should invest (100 - age) \% in stocks (see Malkiel, 2007).

The negative relationship between age and equity exposure in the portfolio is usually derived under the assumption that human capital is close to risk-free, or at least is not correlated with capital return. Benzoni et al. (2007) put forward that in the short run, this correlation is indeed low while in the longer run, labour income and capital income are highly cointegrated, since the shares of wages and profits in national income are almost constant. This finding implies that the risk profile of young workers' labour income is equity-like and that they should therefore hold their financial wealth in the form of safe bonds to offset the high risk exposure in their human capital. Therefore, Benzoni et al. (2007) suggest that the optimal equity share in financial assets is hump-shaped over the lifecycle: cointegration between human capital and stock returns dominates in the first part of working life, whereas the decline in human capital accounts for the negative age-dependency of optimal equity holdings later in life.

All in all, the economic theory suggests a negative relationship between participants' age and pension fund's equity exposure, although a single theory indicates that this relationship might be reversed.

\section{Characteristics of Dutch pension funds}

As in most developed countries, the institutional structure of the pension system in the Netherlands is organized as a three-pillar system. The first pillar comprises the public pension scheme financed on a pay-as-you-go base. It offers a basic flat-rate pension to all retirees. The benefit level is linked to the legal minimum wage. The second pillar provides retired workers with additional income from the supplementary scheme. The third pillar comprises tax-deferred personal savings, which individuals undertake on their own initiative. The Dutch pension system is unique as it combines a state run payas-you-go scheme in the first pillar with funded occupational plans in the second pillar. The first pillar implies that a young individual cedes part of its human capital to elder generations, in exchange for a claim on part of the human capital of future generations. Given the life-cycle hypothesis, this type of intergenerational risk sharing enforces the preference of younger people to invest in equity (Heeringa, 2008). For that reason, we might expect a stronger age effect on equity exposure for Dutch pension funds.

\footnotetext{
${ }^{2}$ A variant of this approach is to buy a house financed by a mortgage loan, as happens much more frequently. Though, this is not a well-diversified portfolio.
} 
The supplementary or occupational pension system in the Netherlands is organized mainly as a funded defined-benefit (DB) plan. The benefit entitlement is determined by years of service and a reference wage, which may be final pay or the average wage over the years of service. The defined-benefit formula takes into account the retirement benefit of the public scheme. The DB pension funds explicitly base their funding and benefits on intergenerational risk sharing (Ponds and Van Riel, 2009). Shocks leading to either a higher or lower funding ratio are smoothed over time, using the long-term nature of pension funds. Pension funds typically adjust contributions and indexation of accrued benefits as instruments to restore the funding ratio. Higher contributions weigh on active participants whereas lower indexation hurts older participants most. ${ }^{3}$ The less flexible these instruments are, the longer it takes to adjust the funding level, and the more strongly will shocks be shared with future (active) participants. Effectively, intergenerational risk sharing extends the risk bearing basis in terms of human capital. The literature on optimal intergenerational risk sharing rules in pension funding concludes that intergenerational risk sharing within pension funds generally should lead to more risk taking by pension funds compared to individual pension plans (e.g. Gollier, 2008; Cui et al., 2009). Thus Dutch pension funds, with their high call on intergenerational risk sharing, may be expected to invest relatively heavily in risky assets.

There are three types of pension funds in the Netherlands. The first is the industry-wide pension fund, organized for a specific sector of industry (e.g. construction, health care, transport). Participation in an industry-wide pension fund is mandatory for all firms operating in the sector. A corporate can opt out only if it establishes a corporate pension fund that offers a better pension plan to its employees than the industry-wide fund. Where a supplementary scheme exists, either as a corporate pension fund or as an industry-wide pension fund, participation by the workers is mandatory and governed by collective labour agreements. The third type of pension fund is the professional group pension fund, organized for a specific group of professionals such as physicians or notaries.

The Dutch pension fund system is massive, covering $94 \%$ of the active labour force. But whereas all employees are covered, the self-employed need to arrange their own retirement plans. As reported by Table 1, the value of assets under management at the end of 2007 amounted to $€ 637$ billion, or $125 \%$ of Dutch gross domestic product (GDP). More than $85 \%$ of all pension funds are of the corporate pension fund type. Of the remaining $15 \%$, most are industry-wide funds, besides a small number of professional group funds. The circa 95 industry-wide pension funds are the dominant players, in terms of their relative share in total active participants (> 85\%) and in assets under management $(>70 \%)$. Almost 600 corporate pension funds encompass over a quarter of the remaining assets, serving $12 \%$ of plan participants. Professional group pension funds are mostly very small funds.

\footnotetext{
${ }^{3}$ In an average wage defined benefit scheme, the accrued pension rights of the active members are often also subject to conditional indexation.
} 
Table 1. Pension funds in the Netherlands (end 2007)

\begin{tabular}{|c|c|c|c|c|c|}
\hline & $\begin{array}{r}\text { Number of } \\
\text { funds }\end{array}$ & Assets & $\begin{array}{r}\text { Active } \\
\text { participants }\end{array}$ & $\mathbf{D B}^{\mathbf{a}}$ & $\mathrm{DC}^{\mathrm{a}}$ \\
\hline \multicolumn{6}{|c|}{$\operatorname{In} \%$} \\
\hline Corporate pension funds & 85 & 27 & 12 & 90 & 10 \\
\hline Industry-wide pension funds & 13 & 71 & 87 & 96 & 4 \\
\hline Professional group pension funds & 2 & 3 & 1 & 83 & 17 \\
\hline \multicolumn{6}{|c|}{ In absolute numbers } \\
\hline Total & 713 & $€ 684$ bln & $5,559,677$ & & \\
\hline
\end{tabular}

Source: De Nederlandsche Bank (DNB). ${ }^{\text {a }}$ Figures as per begin-2006.

In the post-WW2 period, pension plans in the Netherlands were typically structured as final-pay defined benefit plans with (de facto) unconditional indexation. After the turn of the century, pension funds in the Netherlands, the US and the UK suffered a fall in funding ratios. In order to improve their solvency risk management, many pension funds switched from the final-pay plan structure to averagepay plans with conditional indexation. In many cases, indexation is ruled by a so-called policy ladder, with indexation and contribution tied one-to-one to the funding ratio (Ponds and Van Riel, 2009). Under an average-pay plan, a pension fund is able to control its solvency position by changing the indexation rate.

\section{Graph 1. Development of equity exposure}

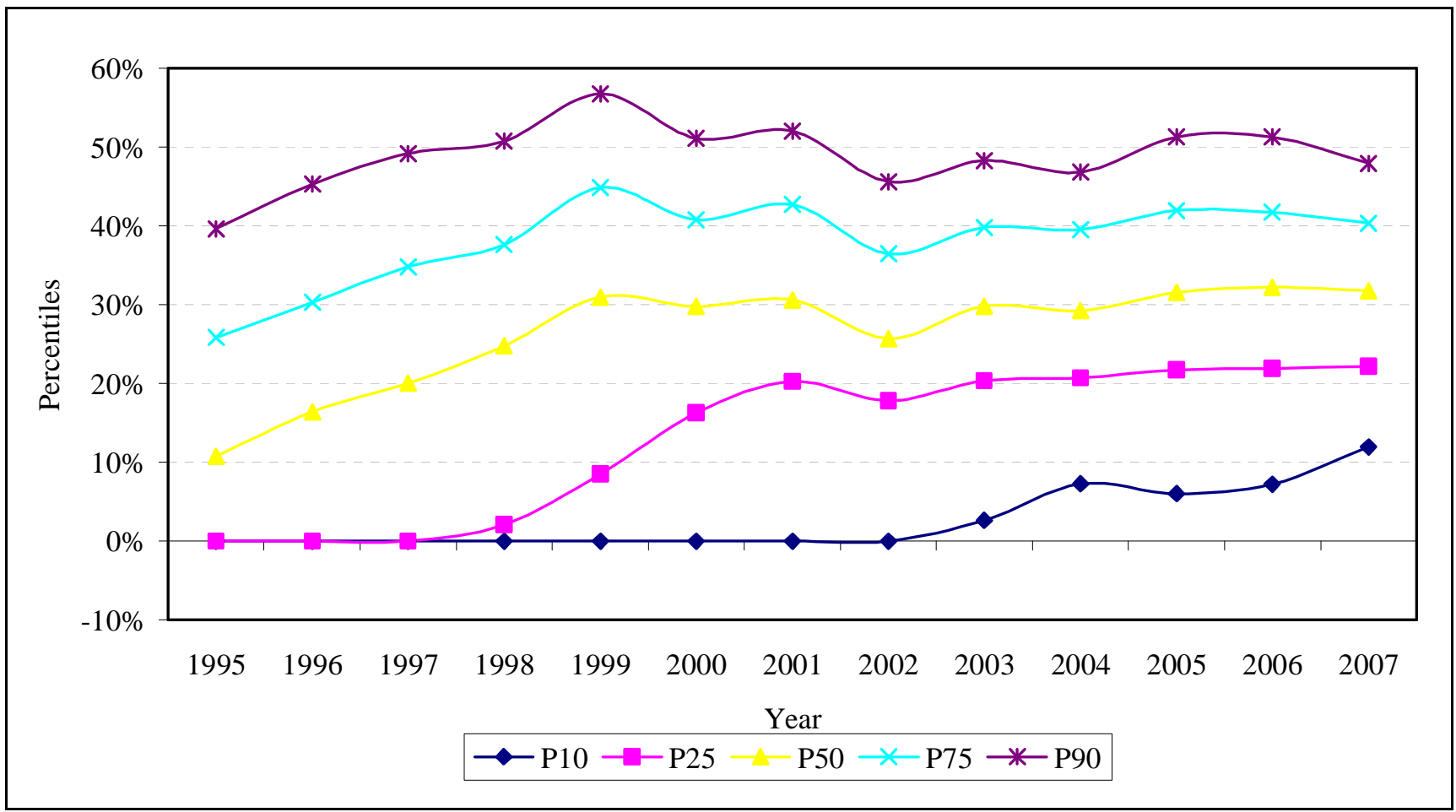

Source: DNB.

Graph 1 documents that Dutch pension funds increased their exposure to equities over time. Between 1995 and 2007 the median equity exposure tripled from $10.8 \%$ to $31.8 \%$. This increase over time is a 
combined effect of more pension funds choosing a positive equity exposure (see $\mathrm{P}_{10}$ and $\mathrm{P}_{25}$ indicating, respectively, the 10th and 25th percentile), and pension funds increasing their exposure.

\section{Empirical results}

Our dataset provides information on pension fund investments and other characteristics for the year 2007. The figures are from supervisory reports to De Nederlandsche Bank, the pension funds' prudential supervisor. Pension funds in the process of liquidation - that is, about to merge with another pension fund or to reinsure their liabilities with an insurer - are exempt from reporting to DNB. The original dataset covers 569 pension funds, of which 472 (or 83\%) invest on behalf of the pension fund beneficiaries, while the remainder are fully reinsured and do not control the investments themselves. Nineteen pension funds do not report the average age of their participants and 54 do not report their strategic asset allocation. Three pension funds with funding ratios higher than $250 \%$ were disregarded, as these are special vehicles designed to shelter savings from taxes and not representative of the pension fund population in which we are interested. Another three pension funds with assets worth over one million euros per participant were excluded for the same reason, as these are typically special funds serving a small number of company board members. These observations as well as fifteen funds, where one or more explanatory model variables were missing, were omitted from the regressions, so that our analysis is based on the remaining 378 pension funds, including all large pension funds.

Table 2. Descriptive statistics of our dataset including 378 pension funds ${ }^{\mathrm{a}}$

\begin{tabular}{|c|c|c|c|c|c|}
\hline \multirow[t]{2}{*}{ Variable } & \multirow[t]{2}{*}{ Mean } & \multirow[t]{2}{*}{ Median } & \multicolumn{2}{|c|}{ Other percentiles } & \multirow{2}{*}{$\begin{array}{l}\text { Weighted } \\
\text { mean }^{b}\end{array}$} \\
\hline & & & $10 \%$ & $90 \%$ & \\
\hline Average age of active participants & 45.2 & 44.6 & 39.9 & 50.1 & 43.1 \\
\hline Average age of all participants & 50.2 & 49.7 & 41.7 & 59.6 & 47.9 \\
\hline Strategic equity exposure (in $\%$ of total investments) & 32.9 & 33.0 & 16.4 & 46.4 & 37.8 \\
\hline Actual equity allocation (in \%) & 33.2 & 33.6 & 17.6 & 46.9 & 37.6 \\
\hline Average assets of participants (in $€ 1,000$ s ) & 81.2 & 58.4 & 11.7 & 155.4 & 42.3 \\
\hline Share of retired (in \%) & 20.9 & 17.4 & 4.0 & 41.5 & 15.6 \\
\hline Share of dormants (in \%) & 42.3 & 40.8 & 23.3 & 65.7 & 50.5 \\
\hline Share of active participants (in \%) & 36.8 & 36.5 & 15.3 & 59.8 & 33.9 \\
\hline Funding ratio (in $\%$ ) & 139.4 & 135.4 & 120.2 & 163.9 & 142.3 \\
\hline Total assets (in $€$ millions) & 1,791 & 150 & 20.3 & 2,153 & 55,400 \\
\hline Total number of participants (in thousands) & 42.3 & 2.5 & 0.4 & 43.3 & 1,099 \\
\hline Defined benefit schemes (in \%) & 0.97 & 1 & 1 & 1 & 1.00 \\
\hline Defined contribution schemes (in \%) & 0.03 & 0 & 0 & 0 & 0.00 \\
\hline Industry-wide pension funds (in \%) & 0.20 & 0 & 0 & 1 & 0.89 \\
\hline Corporate pension funds (in \%) & 0.78 & 1 & 0 & 1 & 0.11 \\
\hline Professional group pension funds (in $\%$ ) & 0.02 & 0 & 0 & 0 & 0.00 \\
\hline
\end{tabular}

${ }^{\mathrm{a}}$ That is, the minimum number of pension funds included in the various regression analyses; ${ }^{\mathrm{b}}$ Weighted with the number of participants per pension funds, as in the weighted regressions.

Source: DNB calculations.

Table 2 provides descriptive statistics of our dataset, with age and strategic equity allocation as key variables. One measure of age is the average age of all participants in the pension fund, including 
active participants, dormants and retirees and equals 50, ranging widely across pension funds between 35 and 79. An alternative definition of age is the average age of active participants, which equals 45 , varying across pension funds from 35 to 63 . The shares of retired and dormant participants also vary strongly across pension funds, reflecting the various positions these pension funds occupy in the life cycle or the dynamic development of their industry or their sponsor firm. The share of equity in the strategic asset allocation averages $32.9 \%$, ranging across pension funds from $0 \%$ to $91 \%$. The actual equity allocation differs from the strategic asset allocation due to free-floating, and appears to average $33.2 \%$. Furthermore, Table 2 presents statistics on other pension fund characteristics, many of which act as control variables in the regression (see below). The $10 \%$ and $90 \%$ percentiles reveal that these characteristics tend to vary strongly. The right-hand column shows the mean values, weighted with the number of participants. For instance, larger funds tend to invest more heavily in the stock market than smaller ones, so that the percentage of all pension assets invested in equities equals $38 \%$, against $33 \%$ for the average pension fund. Finally, the total assets and number of participants statistics explain that a small number of large pension funds dominate the pension market in terms of both total assets and number of participants.

Most life-cycle theories suggest that the relationship between age and equity allocation is linear (Equation (1); see also Malkiel, 2007), while others postulate a non-linear or hump-shaped relationship (Benzoni et al., 2007). Lucas and Zeldes (2009) investigate a relationship between the relative share of active participants and the equity allocation, also assuming a non-linear age pattern: a (constant) effect during the active years compared to the retirement years. Gerber and Weber (2007) regarded two definitions of average age: age of all participants and age of active participants, where the latter implies a non-linear functional form of age, due to the truncation at the retirement age. ${ }^{4}$ Taking the various specifications in the literature into account, we investigate both a linear and a nonlinear version of our model. Our linear age-dependent model for the strategic equity allocation of pension funds reads as:

Strategic equity allocation $_{i}=\alpha+\beta$ age total $_{i}+\gamma \log \left(\right.$ size $_{i}+\delta$ funding ratio $i+\varepsilon \log$ (personal wealth $)_{i}+\zeta D B_{i}+\eta P G P F_{i}+\theta I P F_{i}+u_{i}$

where $i$ represents the pension fund Age total stands for the average age of the total population of each pension fund's participants. ${ }^{5}$ A control variable size is included as larger pension funds tend to invest more in equity (Bikker en De Dreu, 2009, and De Dreu and Bikker, 2009). One argument may be that

\footnotetext{
${ }^{4}$ Alestalo and Puttonen (2006) had data available on active participants only.

${ }^{5}$ Concerning the impact of age on asset allocation, we cannot distinguish between the life-cycle effect, on the one hand, and age dependent risk aversion, on the other hand. However, as that the equity allocation is determined by the pension fund board, the life-cycle effect is more likely to dominate than the risk aversion of the elderly who are not represented in the board.
} 
the pension fund size will go hand in hand with degree of professionalism, investment expertise and willingness to exploit return-risk optimization. The pension fund's size is defined as its total number of participants, where we take logarithms of size to reduce possible heteroskedasticity. The funding ratio is a determinant of equity allocation as a higher funding ratio may stimulate higher risk taking as its provides a larger buffer against equity risk. A higher risk margin for equity is required under the Dutch supervisory regime (Bikker and Vlaar, 2007). Note that - unlike the actual equity allocation the strategic equity allocation is not affected directly by price shocks, although gradually, over time, the strategic equity allocation may be influenced somewhat by trends in the stock market (Bikker, Broeders en De Dreu, 2009). Another explanatory variable is the average personal wealth of the participants in a pension fund, defined as the total pension wealth per plan participant. This variable reflects, on average, the generosity of the pension plan. ${ }^{6}$ Our hypothesis here is that generous pension schemes may go together with relatively higher equity allocations, in a manner similar to the behaviour of private persons who, on average, invest more in equity the larger their savings are. We take logarithms of this variable to reduce possible heteroskedasticity. A set of dummy variables may reflect different behaviour patterns related to different types of pension plan (DB versus DC) or pension fund (professional group pension funds $(P G P F)$ and industry-wide pension funds $(I P F)$ versus corporate pension funds). ${ }^{7}$ Finally, $u_{i}$ denotes the error term.

Our principal non-linear age-dependent model for the strategic equity allocation of pension funds reads as:

Strategic equity allocation $_{i}=\alpha+\beta_{1}$ age active $_{i}+\beta_{2}$ share retired $_{i}+\beta_{3}$ share dormants $_{i}+\gamma \log \left(\right.$ size $_{i}$ $+\delta$ funding ratio $_{i}+\varepsilon \log$ (personal wealth $)_{i}+\zeta D B_{i}+\eta P G P F_{i}+\theta I P F_{i}+u_{i}$

Age active stands for the average age of each pension fund's active participants. Following Lucas and Zeldes (2009) we include ratios of dormants and retired participants (share retired and share dormants, respectively) to incorporate possible further non-linear effects of age on the equity allocation. This equation allows testing whether pension fund boards, populated by employers and employees, show equal versus more interest in active participants compared to dormants and retirees. Alternative non-linear models are Equations (2) and (3), extended by a squared age term.

\footnotetext{
${ }^{6}$ This interpretation assumes a similar average duration of the participants' relationship with the pension fund across pension funds, that is, the sum of the endured employment contract and the endured retirement period. ${ }^{7}$ Willingness of the sponsor company to compensate investment losses could be a relevant explanatory variable also. In practice however, we hardly observe this willingness, except for a few corporate pension funds. Industry wide pension funds service multiple corporations and it is unlikely that losses can be fairly distributed amongst those corporations.
} 
Table 3 reports estimation results of Equation (2), our simplest model. The age coefficient of the average age of all participants is significant and equals - 0.17 (when unweighted; left-hand column), pointing to a negative relation between age and equity allocation. ${ }^{8} \mathrm{~A}$ one year higher average age is associated with a 0.17 percentage point lower equity exposure. ${ }^{9}$ Unweighted estimation attaches equal informational value to each observation of a pension fund, irrespective of whether it has ten participants or 2.5 million. By contrast, weighted regression attributes similar importance to each participant, weighting pension funds proportionally according to size. Such a weighting regression would yield results which are more in line with economic reality. Dropping the largest two pension funds from the unweighted sample would not noticeably affect the regression results (representing less than $1 \%$ of the number of observations; result not shown here), whereas they include no less than $30 \%$ of participants.

Table 3. Impact of the average age of all participants on the strategic equity allocation of pension funds (2007)

\begin{tabular}{|c|c|c|c|c|c|c|}
\hline & \multicolumn{2}{|c|}{ Unweighted } & \multicolumn{2}{|c|}{ SQRT weighting } & \multicolumn{2}{|c|}{ Full weighting } \\
\hline & coeff. & $t$-value & coeff. & t-value & coeff. & $t$-value \\
\hline Average age of all participants & -0.17 & -2.00 & -0.18 & -2.17 & -0.38 & -4.65 \\
\hline Log of total number of participants & 1.59 & 4.33 & 1.25 & 4.52 & 1.22 & 4.45 \\
\hline Funding ratio & 0.20 & 6.83 & 0.24 & 8.66 & 0.29 & 9.55 \\
\hline Log of personal pension wealth & 3.67 & 5.02 & 3.34 & 5.86 & 3.79 & 8.93 \\
\hline Dummy Defined benefit plans & -0.60 & -0.17 & 2.69 & 0.75 & 3.97 & 0.78 \\
\hline Dummy Professional group funds & -1.81 & -0.46 & -0.64 & -0.17 & -0.57 & -0.10 \\
\hline Dummy Industry-wide funds & -0.12 & -0.06 & -0.28 & -0.17 & 0.46 & 0.29 \\
\hline Constant & -13.21 & -1.86 & -18.23 & -2.75 & -18.50 & -2.31 \\
\hline Adjusted $\mathrm{R}^{2}$ & 0.20 & & 0.30 & & 0.45 & \\
\hline Number of observations & 383 & & 383 & & 383 & \\
\hline
\end{tabular}

Therefore, the right-hand column of Table 3 presents a weighted regression using the number of participants as weight. The extreme rise in the adjusted $\mathrm{R}^{2}$ from 0.20 (unweighted) to 0.45 (weighted) reveals that the variation in equity allocation is better explained by the larger pension funds, than by the smaller ones, confirming that weighting makes more sense economically. The age coefficient is both larger (at -0.38) and statistically more significant (at a $t$-value of 4.7). Apparently, the investment behaviour of the larger pension funds is based more strongly on the age-related life-cycle argument. Weighting with the square root of the number of participants as weight takes an intermediate position for almost all coefficients.

Table 4 presents the estimation results for the non-linear specification of our model, based on the average age of active participants (Equation (3)). Comparing these coefficients with those of Table 3, based on the average age of all participants, we observe that the former 'active-age' coefficients have

\footnotetext{
${ }^{8}$ The coefficient would be -0.33 (with $t$-value 2.46 ) when all control variables are deleted.

${ }^{9}$ The Goldfeld-Quandt test indicates that the model's heteroskedasticity does not increase with pension fund size.
} 
a much larger (negative) magnitude and are statistically much more significant. In these alternative estimations, the goodness of fit $\left(\mathrm{R}^{2}\right)$ is also somewhat higher. If we would include the average age of both all participants and active participants, only the latter variable is significant (holding for both weighted and unweighted regressions, not shown here). Indeed, the average age of active participants has been incorporated much more strongly in investment behaviour than that of dormants or retired participants. A one-year increase in the average age of active participants is associated with a drop in equity exposure of around 0.5 percentage point, depending to some extent on the weighting scheme. Our results are similar in direction but not in size to the findings of Gerber and Weber (2007, for Switzerland) and Alestalo and Puttonen (2006, for Finland), who find 'active-age' coefficients of, respectively, $-0.18 \%$ and $-1.73 \%$.

The impact of retirees and dormants is limited if not absent. Only in the full weighting estimates of Table 4 do we find a small reduction of the equity share for pension funds with relatively more retirees or dormants. One percentage point more retirees implies a 0.12 percentage point reduction in the equity allocation, while one percentage point more dormants implies a 0.17 percentage point reduction in the equity allocation. Note that the signs of these variables and the larger value (taken absolutely) of dormants compared to retirees are both in line with theory. The absence of these effects in the unweighted or limited weight model variants implies that only the large pension funds incorporate (parts of) the optimal equity allocation associated with non-active participants. This is confirmed when we drop, as a robustness test, the two largest pension funds (30\% of all participants): the two dependency ratios drop to near or total insignificance (results not shown here). Remarkably, in that case, the absolute value of the age effect increases further to 0.66 .

Table 4. Impact of the average age of active participants on the strategic equity allocation of pension funds (2007)

\begin{tabular}{lrrrrrr}
\hline & \multicolumn{2}{c}{ Unweighted } & \multicolumn{2}{c}{ SQRT weighting } & \multicolumn{2}{c}{ Full weighting } \\
\cline { 2 - 7 } & coeff. & t-value & coeff. & t-value & coeff. & $t$-value \\
\hline Average age of active participants & -0.44 & -2.88 & -0.52 & -4.28 & -0.56 & -6.20 \\
Share of retired participants & 0.04 & 0.89 & 0.01 & 0.14 & -0.12 & -2.60 \\
Share of dormants & 0.09 & 2.09 & 0.03 & 0.62 & -0.17 & -4.73 \\
Log of total number of participants & 1.07 & 2.79 & 1.07 & 3.90 & 0.78 & 2.98 \\
Funding ratio & 0.20 & 6.89 & 0.23 & 8.41 & 0.27 & 9.46 \\
Log of personal pension wealth & 4.03 & 5.21 & 3.49 & 4.99 & 2.23 & 3.74 \\
Dummy Defined benefit plans & 0.37 & 0.10 & 3.80 & 1.08 & 6.00 & 1.27 \\
Dummy Professional group funds & 0.56 & 0.14 & 1.28 & 0.33 & -0.95 & -0.18 \\
Dummy Industry-wide funds & 0.37 & 0.18 & -0.12 & -0.08 & 0.89 & 0.60 \\
Constant & -5.02 & -0.51 & -3.59 & -0.43 & 9.48 & 1.13 \\
Adjusted R & 0.21 & & 0.32 & & 0.52 & 378 \\
Number of observations & 378 & & 378 & & & \\
\hline
\end{tabular}

We consider the results of Table 4 as the most convincing estimates, both from an economic point of view (richer specification of the age-equity relationship) and statistically (higher adjusted goodness of 
fit). The logarithms of the likelihoods of the models in Table 4 are substantially higher than those of Table 3. Likelihood ratio tests reject the Equation (2) models (Table 3) in favour of the Equation (3) models (Table 4). ${ }^{10}$ Therefore, we take Equation (3) as our basic model specification and Table 4 as the most relevant estimates. Continuing with that model, we conclude that while pension funds do incorporate the impact of their active participants' average age on the optimal investment portfolio in their strategic allocation of pension wealth to equities, they pay limited attention to the comparable impact of retirees and dormants.

Turning to the other determinants of the equity allocation in Table 4, we observe that the effect of (the logarithm of) size appears to be positive and sizeable (with values around 1) which tallies with the stylized fact that large pension funds invest more in equity. The marginal effect of size - number of participants - on equity exposure depends on size itself, due to its logarithmic specification. An increase in the number of participants from 10 thousand to 100 thousand is associated with an increase of equity allocation by 2.5 percentage points. One reason may be that larger funds have a more elabourated risk management function, an argument related to economies of scale. Another is that the largest pension funds are of the industry-wide type, which have better abilities to diversify risk over time, that is, over generations. That is particularly true as most of these funds are of the so called mandatory type, that is, corporates in the respective sector are obliged to join. We measure size as the total number of participants. The variable total assets would be an alternative size measure but we already included the per capita wealth which together with the total number of participants reflects total wealth. A drawback of total assets might be that this measure cannot safely be regarded as exogenous, because high equity returns would - for pension funds with a high equity allocation enlarge both their size and their equity exposure. This is the more important given that pension funds do not constantly rebalance their asset portfolios, see Bikker, Broeders and De Dreu (2009). In a robustness check (not shown here), we choose total assets as size measure and use instrumental least squares, but the size coefficient does not change much, and remains significant. ${ }^{11}$

Pension funds with higher funding ratios invest more in equity, because their buffers may absorb mismatch risks. This is also forced by regulation, requiring that the probability of underfunding be less than $2.5 \%$, which enables better funded pension funds to take more risks. The coefficient of around 0.25 implies that an increase of the funding ratio by $1 \%$ translates into an increase of the equity allocation of one quarter percentage point. Note that the funding ratio does not suffer from

\footnotetext{
${ }^{10}$ We take the difference in degrees of freedom into account as Equation (3) has two additional explanatory variables compared to Equation (2). The test is not a pure test on restrictions, as one explanatory variable is different: average age of all participants versus average age of active participants. For this test we exclude the additional five observations in Table 3 (concerning pension funds without active participants), so that we use the same sample for both models.

${ }^{11}$ Since size measured by total assets is highly correlated with size measured by total participants (0.87), the latter may be considered as a relevant and valid instrumental variable for the former.
} 
endogeneity problems, as the dependent variable is the strategic - not the actual - equity allocation. Indeed, the actual equity exposure would be affected as high stock returns simultaneously increase both the funding ratio and the equity allocation (at least under 'free-floating'). Because the strategic equity allocation might nevertheless be adjusted to stock market developments, albeit gradually, we alternatively lag the funding ratio (that is, take 2006 figures) in our robustness analyses, see Section 5. As expected, the results turn out hardly different.

The coefficient of (the logarithm of) personal pension wealth consistently equals around 4 and is statistically significant. The marginal effect of an increase in personal wealth depends on its level, due to the logarithmic specification. Starting from the average value of 81 thousand, an increase by one standard deviation of 78 thousand is associated with an increase of stock allocation by 1.5 percentage points. This confirms that pension funds having a higher wealth per participant invest relatively more in equity, thereby accepting more risk, in line with expectations.

None of the dummy variables for types of pension plan or pension fund carry a statistically significant coefficient. Apparently, the incorporated model variables explain the differences in equity allocations so well that no systematic differences remain across types of pension plan or pension fund.

\section{Robustness checks}

The above specification rests on several assumptions regarding relevant covariates, variable definition and functional form. This section considers various departures from the assumptions underlying this regression.

Table 5. Alternative specifications of the weighted regression model as robustness tests (2007)

\begin{tabular}{|c|c|c|c|c|c|c|c|c|}
\hline & \multicolumn{2}{|c|}{$\begin{array}{l}\text { Strategic equity } \\
\text { allocation (incl. } \\
\text { square age) }\end{array}$} & \multicolumn{2}{|c|}{$\begin{array}{l}\text { Tobit regression: } \\
\text { Equity exposure } \\
(\text { censored at } 0)^{a}\end{array}$} & \multicolumn{2}{|c|}{$\begin{array}{l}\text { Strategic } \\
\text { equity } \\
\text { allocation }\end{array}$} & \multicolumn{2}{|c|}{$\begin{array}{c}\text { Actual equity } \\
\text { allocation }\end{array}$} \\
\hline & coeff. & t-value & coeff. & $t$-value & coeff. & $t$-value & coeff. & t-value \\
\hline Average age of active participants & -0.58 & -6.34 & -0.56 & -6.22 & -0.38 & -2.91 & -0.42 & -3.61 \\
\hline Ditto, squared ${ }^{\mathrm{b}}$ & 0.01 & 1.28 & & & & & & \\
\hline Share of retired participants & -0.12 & -2.61 & -0.12 & -2.62 & -0.19 & -3.53 & -0.21 & -4.38 \\
\hline Share of dormants & -0.17 & -4.85 & -0.17 & -4.75 & -0.23 & -5.17 & -0.23 & -5.79 \\
\hline Log of total number of participants & 0.78 & 3.00 & 0.79 & 3.03 & 1.18 & 4.03 & 0.88 & 3.37 \\
\hline Funding ratio & 0.27 & 9.23 & 0.27 & 9.50 & & & & \\
\hline Funding ratio, lagged (2006) & & & & & 0.19 & 5.72 & 0.16 & 5.31 \\
\hline Log of personal pension wealth & 2.35 & 3.91 & 2.22 & 3.76 & 1.86 & 2.64 & 2.37 & 3.84 \\
\hline Dummy Defined benefit plans & 5.88 & 1.24 & 5.95 & 1.26 & 3.41 & 0.60 & 5.10 & 1.09 \\
\hline Dummy Professional group funds & -1.44 & -0.27 & -0.91 & -0.17 & -0.95 & -0.18 & -14.23 & -2.93 \\
\hline Dummy Industry-wide funds & 0.91 & 0.62 & 0.90 & 0.62 & 0.89 & 0.60 & -0.11 & -0.07 \\
\hline Constant & 10.72 & 1.28 & 9.35 & 1.13 & 9.48 & 1.13 & 24.16 & 2.49 \\
\hline Adjusted $\mathrm{R}^{2}$ & 0.52 & & $0.08^{\mathrm{d}}$ & & 0.43 . & & 0.48 & \\
\hline Number of observations & 378 & & 378 & & 362 & & 367 & \\
\hline
\end{tabular}


In line with the literature, we have so far assumed the effect of the average age of active participants on the equity allocation to be linear. However, Benzoni et al. (2007) suggest that the relation between age and equity exposure may be hump-shaped rather than linear. They suggest that the age effect is positive in the younger age cohorts, due to the positive long-term correlation between capital returns and return on human capital (that is, the wage rate). Benzoni's age-equity relation reaches a maximum around a certain point (seven years before retirement), after which it is downward-sloping, as the longterm correlation of wages and dividends loses relevance. A simple but effective way to allow for a non-linear relationship is the inclusion of a quadratic age term in the regression, known as a secondorder Taylor-series expansion, approximating an unknown, more complex relationship. The respective weighted regression model shows that the signs of both age coefficients are not in line with the assumption of Benzoni et al. (2007) about the investment behaviour of pension funds (Table 5, first column), as the sign of the squared terms has the 'wrong' sign. Hence, we find no support for Benzoni's theory.

With regard to the dependent variable 'strategic equity allocation' several robustness checks may be considered. A small number (4) of pension funds have zero equity exposure. This runs counter to the OLS assumption that the dependent variable is of a continuous nature. In practice, equity exposure is censored at $0 \%$ and $100 \%$. One may further argue that moving from zero equity allocation to a positive fraction is an intrinsically different decision than raising an already positive equity exposure. One way to address this is to omit zero observations for equity, restricting attention to funds with positive equity allocations. This does not alter the essence of the results (not shown here). A more elegant alternative approach is the Tobit model which takes this kind of censoring into account. Table 5, second column, reports the Tobit outcomes. The effect of age and the other OLS results from Table 4 do not change substantially.

Shocks in equity prices affect the funding ratio, but as observed in Section 4 they may also have a certain impact on the strategic equity allocation, which could create an endogeneity problem. For this reason we here lag the funding ratio, see the 3rd column in Table 5. Although the sample is somewhat smaller, the results hardly change, particularly in terms of significance. The magnitude of the (lagged) funding ratio coefficient is slightly smaller here than in the unlagged regression.

The actual equity exposure of pension funds may differ from the strategic equity allocation where pension funds do not constantly rebalance their portfolio after stock price changes. Bikker, Broeders and De Dreu (2009) document that pension funds' assets are indeed partially free-floating, meaning that their asset allocation is not constantly adjusted. As strategic asset allocation reflects the real decision of the fund it is better suited for determining decision-making and behaviour of pension 
funds. On the downside, however, this may affect comparability with other studies, such as Alestalo and Puttonen (2006) and Gerber and Weber (2007). Also, while the strategic asset allocation reflects intention, it does not give actual behaviour. Table 5, right-hand columns, documents a regression results for the actual stock allocation. To avoid endogeneity, we lag the funding ratio by one year. Sign and size of the coefficients hardly change, though the magnitude of the (lagged) funding ratio coefficient is slightly smaller than it is in the other regressions.

Finally, we also applied our model to the strategic bond allocation instead of the strategic equity allocation, where we expect a positive and not a negative sign for the age dependency. The results (not shown here) deviate as bonds are not exactly the complement of equity, due to other investment categories. These estimates confirm the age-bond relationship: the strategic bond exposure is significantly higher when the average age of active participants is higher.

\section{Conclusion}

This paper addresses the effect of the average age of pension funds' participants on their strategic equity allocation. Our first and key finding is that Dutch pension funds with higher average age of their participants have significantly lower equity exposures than pension funds with younger participants. This negative age-dependent equity allocation may be interpreted as an (implicit) application of the optimal life-cycle saving and investing theory. The basic version of this theory assumes a low correlation between wage growth and stock returns. It predicts that the vast amount of human capital of the young have a strong impact on asset allocation because of risk diversification considerations, as human capital has a different risk profile than financial capital. As the average participant age varies mainly across pension funds, and hardly or not over time, the awareness of the optimal age-equity relationship for pension funds, and its incorporation in the strategic equity allocation, is notable.

A second finding is that the average age of active participants has a much stronger impact on investments than the average age of all participants. The age of retired and dormant participants is hardly incorporated, if at all, in the investment policy. This is in line with the fact that the pension fund boards are dominated by employers and employees and may be mainly interested in optimizing expected benefits for active participants.

A third result is that the age effect is much stronger in larger pension funds than in smaller funds. Apparently, larger funds' investment behaviour is more precisely based on the age-dependency from the life-cycle hypothesis. A non-linear age effect allowing a hump-shaped pattern, as suggested by Benzoni et al. (2007), could not been confirmed. However, other factors significantly influencing the 
strategic equity allocation are a pension fund's size, funding ratio, and average personal pension wealth of participants, which all have positive coefficients. We do not observe any effect of pension fund type or pension scheme type on funds' equity exposure.

This research provides valuable insights for contemporary policy issues to do with the ageing of society. As society grows older, pension funds will adapt their investment strategies to the needs of the average active participant who will get older over time. This may result in a safer investment strategy. According to the life-cycle saving and investing theory, this is not optimal for younger participants with low-risk human capital, who will not be fully able to utilize the diversification between human and financial capital. At the same time, this policy may not be conservative enough for retirees, whose interests are not weighted that heavily by the pension fund boards. This leads to the recommendation that it might be optimal for pension funds to replace the average age-based policy by a cohort-specific investment policy as has been suggested by Teulings and De Vries (2006) and Ponds (2008).

\section{References}

Alestalo, N., and V. Puttonen, 2006, Asset allocation in Finnish pension funds, Journal of Pension Economics and Finance 5, 27-44.

Bader, L.N., and J. Gold, 2003, Reinventing pension actuarial science, In: The Pension Forum 14, no. $1,1-13$.

Benzoni, L., P. Collin-Dufresne, and R.S. Goldstein, 2007, Portfolio Choice over the Life-cycle when the Stock and Labour Markets are Cointegrated, Journal of Finance 62, 2123-2167.

Bikker, J.A., P.J.G. Vlaar, 2007, Conditional indexation in defined benefit pension plans in the Netherlands, Geneva Papers on Risk and Insurance - Issues and Practice 32, 494-515.

Bikker, J.A., D.W.G.A. Broeders and J. de Dreu, 2009, Stock market performance and pension fund investment policy: rebalancing, free float, or market timing?, International Journal of Central Banking (forthcoming).

Bikker, J.A., and J. de Dreu, 2009, Operating costs of pension funds: the impact of scale, governance and plan design, Journal of Pension Economics and Finance 8, 63-89.

Bodie, Z., 1990, The ABO, the PBO, and pension investment policy, Financial Analysts Journal 46, 27-34.

Bodie, Z., 1995, On the risk of stocks in the long-run, Financial Analysts Journal, 18-22.

Bodie, Z, R. C. Merton and W.F. Samuelson, 1992, Labour supply flexibility and portfolio choice in a life cycle model, Journal of Economic Dynamics and Control 16, 427-449.

Bovenberg, L., R. Koijen, T. Nijman, and C. Teulings, 2007, Savings and investing over the life cycle and the role of collective pension funds, De Economist 155, 347-415.

Campbell J.Y, and L.M. Viceira, 2002, Strategic asset allocation. portfolio choice for long-term investors, Oxford University Press.

Cocco J.F., F.J. Gomes, and P.J. Maenhout, 2005, consumption and portfolio choice over the life cycle, In: The Review of Financial Studies 18, 491-533.

Cui J., F. De Jong, and E.H.M. Ponds, 2009, Intergenerational risk sharing within funded pension schemes, Working Paper, Tilburg University (http://papers.ssrn.com/sol3/papers.cfm?abstract_id $=989127$ ).

De Dreu, J., and J.A. Bikker, 2009, Pension fund sophistication and investment policy, DNB Working Paper no. 211, De Nederlandsche Bank, Amsterdam.

Gerber, D.S., and R. Weber, 2007, Demography and investment behaviour of pension funds: evidence for Switzerland, Journal of Pension Economics and Finance 6, 313-337. 
Gollier, C., 2008, Intergenerational risk sharing and risk taking of a pension fund, Journal of Public Economics 92, 1463-1485.

Heeringa, W., 2008, Optimal life cycle investment with pay-as-you-go pension schemes: a portfolio approach, DNB Working Paper no. 168, De Nederlandsche Bank, Amsterdam.

Hoevenaars, R.P.M.M., 2008, Strategic asset allocation \& asset liability matching, $\mathrm{PhD}$ thesis Maastricht University.

Ibbotson R.G, M.A. Milevsky, P. Chen, and K.X. Zhu, 2007, Lifetime financial advice: human capital, asset allocation, and insurance, CFA Institute, Research Foundation Publications, April, 1-95.

Lucas D.J., and S.P. Zeldes, 2006, Valuing and hedging defined benefit pensions obligations: the role of stocks revisited, Working Paper, Columbia University Graduate School of Business.

Lucas, D.J., and S.P. Zeldes, 2009, How should public pension plans invest? American Economic Review: Papers \& Proceedings 99, 527-532.

Malkiel, B.G., 2007, A random walk down Wall Street: the time-tested strategy for successful investing, W.W. Norton \& Company, New York.

Merton, R.C., 1969, Lifetime portfolio selection under uncertainty: the continuous-time case, The Review of Economics and Statistics 51, 247-257.

Ponds E.H.M., 2008, Naar meer jong en oud in collectieve pensioenen, Inaugural Speech 11 April 2008, Tilburg University.

Ponds E.H.M., and B. Van Riel, 2009, Sharing risk: the Netherlands: new approach to pensions, in: Journal of Pension Economics and Finance 8, 91-105.

Teulings, C., and C. de Vries, 2006, generational accounting, solidarity and pension losses, De Economist 146, 63-83.

Samuelson, P.A., 1969, Lifetime portfolio selection by dynamic stochastic programming, Review of Economic and Statistics 51, 247-257. 